\title{
BRITISH BIRDS
}

WRITTEN AND ILLUSTRATED BY

A. THORBURN, F.Z.S.

SUPPLEMENTARY PART

WITH TWO PLATES IN COLOUR

LONGMANS, GREEN AND CO.

39 PATERNOSTER ROW, LONDON

FOURTH AVENUE \& 3 OTH STREET, NEW YORK

BOMBAY, CALCUTTA, AND MADRAS

1918

All rights reserved 



\section{Archibald Tharburn \\ British birds. Swpplementary part}

\section{CONTENTS}

\section{PLATE $80 \mathrm{~A}$}

Hebridean Song-Thrush. Turdus hebridensis ST. KILDA Wren. Troglodytes hirtensis Irish Coal-Titmouse. Parus hibernicus Willow-Titmouse. Parus kleinschmidti MARSH-TITMOUSE. Parus palustris Greater Redpolinota rostrata

\section{PLATE $80 \mathrm{~B}$}

Eastern Pied Wheatear. Saxicola pleschanka . RüPPELL'S WARBLER. Sylvia rüppelli.

MOUStached WARBLER. Lusciniola melanogopogon Olivaceous Warbler. Hypolais pallida . . Scottish Crossbill. Loxia scotica . . 8
PAGE 3 5 6 7 7 7 8

$$
\text { Cat }
$$

Species noticed in this Supplement, but not figured:

North African Black Wheatear. Saxicola syenitica . . . . . . 10

Eastern Great Reed-Warbler. Acrocephalus orientalis . . . . . . 10 Eastern Short-toed Lark. Alauda longipennis . IO CALANdra LARK. Melanocorypha calandra . . Io Semi-palmated Ringed Plover, Egialitis semi. palmata. . . . . . . . I0 Cape Verde Litrle Shearwater. Puffinus boydi II North Atlantic Great Shearwater. Puffinus borealis.

Io




\title{
BRITISH BIRDS
}

When the bird was put up it was observed that it differed from our Common Wheatear by being considerably darker, looked smaller and seemed to show less white on the rump when in flight (v. Annals Scottish Natural History, rgio, p. 2).

A second specimen, also a female, was obtained on the island of Swona, Orkney, on November Ist, I9I6.

No other examples are known to have occurred in the British Islands. A figure of the male in adult plumage is given in vol, i. plate 3 , described p. 17 .

\section{RÜPPELL'S WARBLER. \\ Sylvia rippelli, Temminck. \\ Plate 8OB.}

Two examples of this beautiful little warbler, both males, were obtained at Hastings, Sussex, on May 5th, I9I4. According to Dresser's Birds of Europe, it inhabits Greece, Asia Minor, Palestine, and Algeria, wintering in North Africa.

Rüppell's Warbler is partial to bushy places, either near water or in dry localities, and builds its nest, composed of dead grasses with a lining of hair, in bushes.

The eggs are dull white, with blurred brownish markings.

I have figured a male and female on the plate.

\author{
MOUSTACHED WARBLER. \\ Lusciniola melanogopogon (Temminck). \\ Plate 8OB.
}

A male of this species, which is related to our Sedge-Warbler, was shot at St. Leonards-on-Sea, Sussex, on April I2th, I9I5.

It breeds among the reed-beds and marshes of the Mediterranean countries, being a resident in the southern parts of Europe and North Africa, whilst eastwards in Asia it ranges to Turkestan. In winter it occurs as far as N.W. India.

In habits the Moustached Warbler is shy and retiring, and builds its nest of grasses and rootlets in the dense cover of reed-beds.

According to Dresser, the four or five eggs resemble the Sedge-Warbler's, but are rather greener in colour and minutely spotted with brown. 
THE OLIVACEOUS WARBLER

\section{THE OLIVACEOUS WARBLER.}

Hypolais pallida (Hempr. and Ehr.).

Plate 8ob.

The Olivaceous Warbler has occurred but once in the British Islands, viz. near Hastings, on May 2oth, I9I 5.

It breeds in the south-eastern countries of Europe, ranging still further eastwards to Turkestan and Persia, and is also found in North-east Africa. It winters in tropical Africa.

Dresser informs us (A Mamual of Palaarctic Birds) that "it frequents groves, orchards, and bush-covered places both in the valleys and in damp localities and also to the altitude of 6000 feet."

The song is said to resemble that of the Icterine Warbler.

The nest, placed in the fork of a branch, is built of dry grasses, etc., with a few horse-hairs, and contains four to five eggs, in ground-colour grey tinged with pink, with dark spots and markings.

The various Warblers shown on this plate were drawn from specimens kindly lent by Lord Rothschild.

THE ST. KILDA WREN.

Troglodytes hirtensis, Seebohm.

Plate 80a,

Although noted as a resident in St. Kilda by Martin as far back as 1697, this large and pale-coloured race of the Wren was unknown to science until 1884, when Seebohm described it in the Zoologist from examples obtained by Dixon in the same year. It is entirely confined to the islands of the St. Kilda group, and differs from our Common Wren not only in size but in the general greyer tone of its plumage, especially on the breast, which is "mealy" in colour, while the upper parts are more distinctly barred and the bill and feet are larger. According to Dr. Eagle Clarke (Studies in Bird Migration), "it breeds on Hirta, Soay, Dun, Boreray, and Stack an Armin."

He "found the Wren in all parts of Hirta, among the boulders that fringe the head of the bay, in the walls and cleits, among the crofts, on the screes and rocks 


\section{BRITISH BIRDS}

on the hillsides, and in the faces of the great cliffs." Three nests were shown him. "One of these was placed in a hole worked in a mass of dead thrift on the face of a cliff; the other two were placed between the stones forming the inner walls of cleits, and were in excellent condition.

"All these nests were composed of the blades and stems of grasses, small tufts of grass, a little moss and dead bracken, and were lined entirely with white feathers of a gull, or with a mixture of moss and white feathers." The bird shown in the plate was painted from a specimen in the Royal Scottish Museum.

Another form of Wren is found in the Shetlands, distinguished from our common species by its larger and heavier bill and richer brown colouring.

\section{THE IRISH COAL-TITMOUSE. \\ Parus hibernicus, Ogilvie-Grant. \\ Plate 8Oa.}

This bird, which is a sub-species of our well-known British Coal-Tit, is confined to Ireland, and the adults may be distinguished by having the white cheek patches and occipital spot suffused with sulphur-yellow and also by the golden russet tint on the sides of the breast and flanks. Mr. Ogilvie-Grant, writing in the Ibis for July I9II, says, "It is well known that the young of Parus britannicus and its near allies differ from the adult birds in having the sides of the head, as well as the breast and belly, washed with yellow. The persistency of this juvenile character in the adult of $P$. hibernicus seems to indicate that it is of very ancient origin, much more so than its British representative: it seems to represent a pre-Glacial type which has survived in the western and southern parts of Ireland."

According to the same authority the typical British Coal-Titmouse is also found in parts of Ireland.

I have already referred to the Irish race of this Titmouse in vol. i. p. 66. 



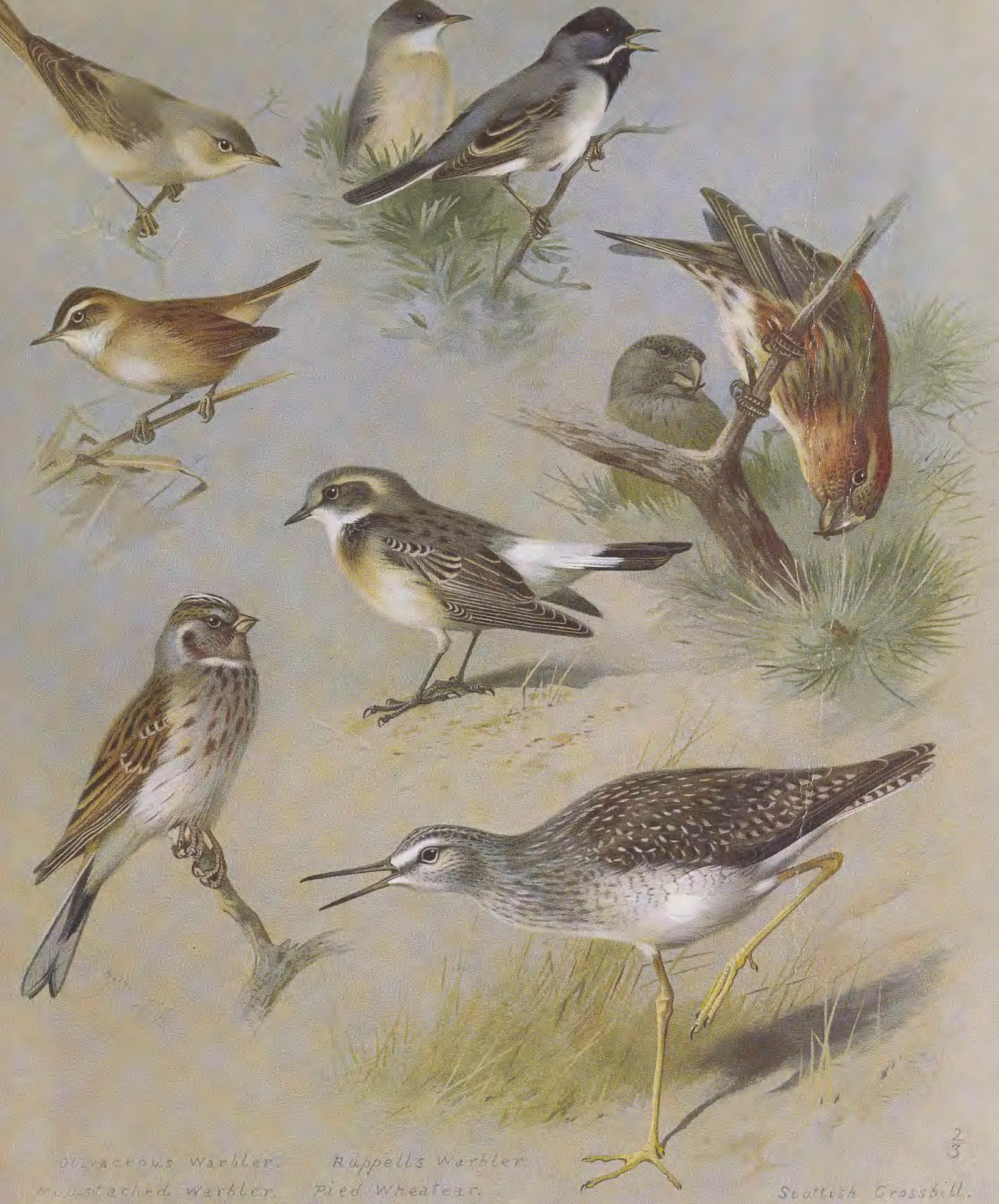





\title{
THE WILLOW-TITMOUSE
}

\section{THE WILLOW-TITMOUSE.}

\author{
Parus kleinschmidti, Hellmyr.
}

Plate 8OA.

This Titmouse is regarded by the latest authorities as a sub-species of the Northern Marsh-Titmouse $P$. borealis, and so closely resembles our Common Marsh-Tit that it was not distinguished till 1897. When compared, the chief difference between the two lies in the colour and texture of the feathers of the crown of the head, which in the Marsh-Titmouse is of a glossy black, while in the Willow-Tit this part is duller in tone; the variation however, although noticeable in a living specimen, is difficult to show in a colour reproduction. The tail feathers in the Willow-Titmouse also appear to be more graduated than in that of its near ally.

The distribution in the British Islands of the Willow-Titmouse does not yet appear to have been fully ascertained, but according to the B.O.U. List of British Birds 1915, it is "resident and confined to the mainland of Great Britain, where it is widely but locally distributed as far north as the Moray Firth."

The "Marsh-Tits" found in Scotland all appear to belong to this form (WillowTit), and as a good deal of interest has been raised among ornithologists by the different races, I have given on the plate pictures of both the Willow and MarshTitmice, for convenience of comparison. These were taken from specimens in the Royal Scottish Museum.

\section{THE GREATER REDPOLL. \\ Linota rostrata (Coues). \\ Plate 8OA.}

The Greater Redpoll is a native of Greenland, but also visits the northern parts of America in winter. It is usually considered a rare visitor to the British Islands, although found by Dr. Eagle Clarke to be extremely abundant during his visit to Fair Isle, Shetlands, in the autumn of 1905. He describes in his Studies in Bird Migration how the birds "moved about in large parties, and frequented the enclosures near the houses, being attracted by the seeds of numerous weeds which 


\section{BRITISH BIRDS}

abounded there." In colour this species is darker and browner and has the plumage more heavily streaked than in the Greenland Redpoll.

\section{THE GREENLAND REDPOLL. \\ Linota hornemanni, Holböll. \\ Plate. 8OA.}

A native of Greenland, this large pale coloured species occurs also in Iceland, Jan Mayen, Spitsbergen and Franz-Joseph Land, and visits North America in winter.

Although only a rare straggler to the mainland of Great Britain, it appears to be less so in the Shetlands where, on Fair Isle, Dr. Eagle Clarke observed no less than five during his visit there in the autumn of 1905 .

I quote the following notes from his Studies in Bird Migration: "The first to come under notice were a party of three, consisting of an adult male and two younger birds, which appeared on I8th September.

"These birds frequented an enclosure in front of one of the crofter's houses, where they fed on the seeds of weeds for several days, and were exceedingly tame.

"On the 29th a second adult male was observed seeking food among some low herbage; and on the Ioth October another young bird was found.

"In life these birds, especially the adults, appeared to be almost entirely white, and this fact and the habit of puffing out their fluffy feathers, rendered them exceedingly pretty and conspicuous objects."

The bird drawn on the plate was taken from one of the above-mentioned specimens, an adult male now in the Royal Scottish Museum.

\section{THE SCOTTISH CROSSBILL. \\ Loxia scotica, Hartert.}

Plate 8OB.

The Scottish form of our Common Crossbill ( $v$. vol. i. plate 17) differs only in having a larger and heavier bill. It inhabits the pine woods of the Highlands of Scotland, where it breeds, occasionally wandering to the Lowlands in winter. 


\title{
THE SCOTTISH CROSSBILL
}

The principal figure in the plate shows a male in the interesting intermediate stage, the time of change from the brownish-green striped plumage of immaturity, to the red dress of the fully adult.

The second figure represents a female, both painted from specimens in the Royal Scottish Museum.

\author{
THE PINE BUNTING. \\ Emberiza leucocephala, S. G. Gmelin. \\ Plate $80 \mathrm{OB}$
}

On this plate is shown a sketch of the only example taken in the British Islands of this rare species, a male in winter plumage, obtained at Fair Isle, Shetlands, on October 3oth, I9I I. It is now in the Royal Scottish Museum.

For an adult bird in summer, see vol. i. plate I7, described page I23.

\section{THE YELLOWSHANK.}

Totanus flavipes (Gmelin).

Plate 80 .

For description of this species see vol. iv. page 46. The bird represented in the plate was obtained at Fair Isle, Shetlands, in September Igro, and is now in the Royal Scottish Museum. 


\section{BRITISH BIRDS}

The following birds, mostly racial forms, have been recorded lately as having occurred in the British Islands, but are not figured.

They are given under binomial names.

North African Black Wheatear, Saxicola syenitica, Heuglin. One obtained at Pevensey, Sussex, June 7 th, I9I5. This bird differs from the typical European form in having the black of a browner tone and the black tips to the tail-feathers broader (ข. Witherby's British Birds, January igi6).

Eastern Great Reed-Warbler, Acrocephalus orientalis (Temm. and Schleg.). One picked up dead, St. Leonards, Sussex, August 24th, I9i6. Differs from the Great Reed-Warbler in its smaller size and in the wing formula (v. Witherby's British Birds, April 1917).

Eastern Short-toed Lark, Alauda longipennis, Eversmann. One obtained at Fair Isle, Shetlands, November I Ith, 1907. It is paler in the colour of the upper parts and has the wings generally a little longer than in the typical form ( $v$. Scottish Naturalist, 1915, p. 100).

Calandra Lark, Melanocorypha calandra (Linnæus). Two obtained near St. Leonards, Sussex, May I6th and I7th, I916 (v. Witherby's British Birds, April I9I 7).

Semi-palmated Ringed Plover, Agialitis semipalmata (Bonaparte). One obtained April 8th, I9I6, at Rye, Sussex. This American form of Ringed Plover differs from our bird not only in the semi-palmation of the feet, but in having less black on the head, neck and breast (v. Witherby's British Birds, April I9I7). 


\section{BRITISH BIRDS}

Cape Verde Little Shearwater, Puffinus boydi, Mathews. One picked up at Pevensey, Sussex, December 4th, 1914, and another obtained at St. Leonards, Sussex, January 2nd, 1915. It differs very slightly from the Little Dusky Shearwater, Puffinus assimilis, figured in vol. iv., plate 79, but is rather browner in the colour of the upper parts and has the under tail-coverts darker ( $v$. Witherby's British Birds, January 1916).

North Atlantic Great Shearwater, Puffinus bovealis, Cory. One obtained at St. Leonards, Sussex, March I4th, I9I4. Differs chiefly from the Mediterranean Great Shearwater, Puffinus kuhli, in having a larger and heavier bill ( $v$. Witherby's British Birds, January 1916). 

- 5 
SMITHSONIAN INSTITUTION LIBRARIES



$$
\text { 39088015709231 }
$$

